\title{
Observing Family Functions by Considering Father Occupation in Adolescent Groups
}

\section{Aslıhan Fidancı*, Mustafa Ulku Uckan, Ismail Arslan, Oguz Tekin, Gokce Iscan, Duygu Yengil Taci, Izzet Fidancı, Elif Cirit, Adil Çetin}

Department of Family Medicine, Training and Research Hospital, Ankara, Turkey

\author{
Email address: \\ izzetfidanci@gmail.com (A. Fidanc1)
}

\section{To cite this article:}

Aslıhan Fidancı, Mustafa Ulku Uckan, Ismail Arslan, Oguz Tekin, Gokce Iscan, Duygu Yengil Taci, Izzet Fidancı, Elif Cirit, Adil Çetin. Observing Family Functions by Considering Father Occupation in Adolescent Groups. Journal of Family Medicine and Health Care.

Vol. 1, No. 1, 2015, pp. 11-15. doi: 10.11648/j.jfmhc.20150101.14

\begin{abstract}
Objectives: The purpose of our study is to analyze the effect of father's profession to family functions in adolescants. Material and Methods: Our study was performed at Ankara Training and Research Hospital Family Medicine Polyclinics and the schools in Bahçelievler, Cebeci. In this study 285 adolescents between the age of 11 and 21 were included. A questionnaire consisting of 60 questions of Family Assessment Device has been applied to adolescents. Results: It was seen that father's profession and reading books regularly have affected the relation function together in adolescents. Whereupon reading books regularly effecting the relation function, was analyzed in different father's profession and it was seen that the relation function has been better in group of educationist then the other father's profession groups. Similar to this, it was observed that father's profession and reading books regularly have effected the general function together and the general function has been better in group of educationist then the other father's profession groups. It was also seen that the number of individuals in family has affected the behaviour reaction function. Conclusions: The healthy of society is related with its individuals. Families are the smallest units of society and they must bring up the healthy individuals. Socializing the healthy individuals is closely related with family functions. Family function in adolescents Puberty is a transition period from childhood to adulthood and adolescent's future lifetime was formed in puberty. Parent's awarding of this will educate more healthy adolescents; therefore beneficial persons will take part in society. To achieve this, child and adolescent growth programs must be generalized. is affected from a lot of factors. One of these factors is adolescent's father's profession.
\end{abstract}

Keywords: Family Functions, Adolescent, Father's Profession, Family Assessment Device

\section{Introduction}

There are different definitions of "adolescent" in every society. Adolescent problems also differ. Conceptual definitions in our study are grouped under four main titles:

- Family life cycle

- Adolescence

- Family functions

- Parent occupations

\subsection{Family Life Cycle}

Periods between starting a family and completion of a family's life is studied under 'family life cycle' concept.(1) Knowing about these periods is helpful in solving the problems faced by the family.

\subsection{Family Life Cycle(2)}

- Marriage

- Birth of children

- School years and adolescence period

- Graduation and starting work

- Children leaving home

- Retirement

\subsection{Adolescence Period}

Adolescence period is one of the important periods in family life cycle (11-21 years of age). It is a period in which the child turns into an adult. It is a period in which the individual maturalizes psychologically, biologically and morally.(3)

The individual starts to get away from parental effect and 
family and this brings many problems along.

Family relations significantly effect the behaviours the adolescent will adopt in the years ahead.(4)

\subsection{Family Functions}

The first and most important function of a family is to bring individuals to a satisfactory level socially, psychologically and biologically.(5)

Epstein emphasized on these family function concepts (5):

- Problem solving

- Communication

- Roles

- Emotional responsiveness

- Showing required interest

- Behaviour control

Non-functional families face many problems.

While functional families search for a solution method when a family member faces a problem, families without a similar functional response are also observed.(6)

Family functions regulate family relations. It is extremely important in development of a child. Family functions are also important in adolescence. Bad family relations, hard-lines of parents, presence of conflict, inability to perform family functions adversely effect the progress of adolescents.(7)

\subsection{Occupation of the Parents}

Factors affecting the child upbringing method of the parent (8):

- Personal characteristics of the parent and child

- Gender of the child

- Cultural structure of the society

- Occupation, sociocultural condition of the parent

Occupation groups were examined under two groups in a study; entrepreneur and bureaucrat.(8)

The differences mentioned below were determined among the concepts emphasized in child upbringing in this study:

Entrepreneur occupation : Independence, self-reliance

Bureaucratic occupation : Importance of social cohesion

Behaviour of middle and working class parents towards their children when playing was observed in another study (9),

Working class : it was observed that they stayed away and just watched their children when playing.

Middle class : stayed closer to their children and talked to them when playing.

As we can see, the occupation of parents effects the way a child is raised.

Our aim in this study was to determine the effect of the occupation of fathers on family functions in adolescence.

\section{Materials and Methods}

The project planned observationally, analytically and prospectively in scope of Family Guidance Project was made between January 2012 and March 2012 in S.B. AERH Family Practice polyclinics and schools in Bahçelievler and Cebeci districts.
285 adolescents between the ages 11-21 were included in the study. 60 questions were asked using "Mc.Master Family Evaluation Scale" and family functions were evaluated. Written consent was taken from all adolescents who participated in the research.

Mc. Master Family Evaluation Scale

Reliability of the scale for our country was provided by psychiatry, psychology and social service experts.(10) The scale contains 60 items and 7 sub-scales:

1. Problem solving

2. Communication

3. Roles

4. Emotional responsiveness

5. Ability to show required interest

6. Behaviour control

7. General functions

Choices for 60 questions are mentioned below:

- Totally agree

- Mostly agree

- Partially agree

- Disagree

Adolescents who joined the study were asked questions about the regularity of sports and reading. Father occupations of adolescents were separated into 5 groups:

1. Health care provider

2. Security

3. Technician

4. Educator

5. Self-employed

Data were evaluated by SPSS statistical package programme version 16.00 .

First the average scores of factors were calculated. The mutual effects of factors were analyzed by FACTORIAL ANOVA test. In the next stage, data were compared by MANN-WHITNEY-U and WILCOXON W, Spearman Correlation method.

\section{Findings}

285 Adolescents (138 male, 147 female) were included in our study. Average male age was determined as $15,7 \pm 1,4$ and average female age as $15,8 \pm 1,36$.

Among father occupations, there were 44 health care providers, 74 security staff, 55 technicians, 55 educators and 57 self-employed individuals. Father occupation distribution of adolescents who completed the scale is shown in Table 1.

Table 1. Distribution of Father Occupations.

\begin{tabular}{ll}
\hline Health care providers & $15 \%$ \\
Security staff & $27 \%$ \\
Technical & $19 \%$ \\
Educator & $19 \%$ \\
Self-embloyed & $20 \%$ \\
\hline
\end{tabular}

Regular reading characteristics of adolescents are shown in Table 2. Regularity of sports in adolescents is shown in Table 3. First of all Mc.Master scale factor scores were generally lower 
in adolescents whose fathers were health care providers. (indicator of a positive situation) But no statistically significance was found in direct comparison among groups (Table 4).

According to factorial ANOVA method, father's occupation was found effective on "communication factor" together with regular reading (Table 5). When it was determined that father's occupation and regular reading are both effective on "communication factor", MANN WHITNEY U and WILCOXON W methods were used in order to determine if there is a difference between father occupations. It was considered that communication skills would be higher in adolescents reading regularly and whose fathers are educators (Table 6).
Table 2. Regular Reading Rates of Genders.

\begin{tabular}{ll}
\hline Gender & Regular Reading (\%) \\
\hline Male & $55(39,9)$ \\
Female & $94(63,9)$ \\
Total & $149(52,3)$ \\
\hline
\end{tabular}

Table 3. Regular Sports, Reading Rates of Genders.

\begin{tabular}{ll}
\hline Gender & Regular sports (\%) \\
\hline Male & $84(60,9)$ \\
Female & $57(38,8)$ \\
Total & $141(49,5)$ \\
\hline
\end{tabular}

Table 4. Mc. Master factor scores according to father occupation groups.

\begin{tabular}{llllllll}
\hline Occupation & Number & P.S. & COM. & RL. & E.R. & Shw.R.I. & B.C. \\
\hline Health care provider & 44 & 1.89 & 1.87 & 1.97 & 1.84 & 1.82 & 1.86 \\
Security & 74 & 2.02 & 2.03 & 1.96 & 1.94 & 1.86 & 1.96 \\
Technician & 55 & 2.1 & 2.06 & 2.1 & 1.97 & 1.92 & 1.93 \\
Educator & 55 & 2.01 & 2.04 & 2.09 & 1.92 & 1.92 & 1.85 \\
Self-employed & 57 & 1.95 & 2.09 & 1.97 & 2.07 & 1.92 & 1.97 \\
\hline
\end{tabular}

P.S. $=$ Problem solving, COM. $=$ Communication RL. $=$ Roles, E.R. = Emotional responsiveness, Shw. R. I. = Showing required interest, B.C. $=$ Behaviour control, R.F. = Required functions

Table 5. Factors Effective on Communication Factor.

\begin{tabular}{lllc}
\hline Source & $\begin{array}{l}\text { Sum of TypeIII } \\
\text { Square }\end{array}$ & Mean square & P \\
\hline Father's occupation &, 369 &, 092 &, 801 \\
$\begin{array}{l}\text { Regular reading } \\
\text { Father's occupation * } \\
\text { regular reading }\end{array}$ &, 807 &, 807 &, 059 \\
\hline
\end{tabular}

Table 6. Communication skill rates of educator fathers.

\begin{tabular}{lll}
\hline & Communication \\
\hline & Mann-Whitney U & 196,000 \\
Educator & Wilcoxon W & 826,000 \\
& $\mathrm{Z}$ & $-2,706$ \\
& $\mathrm{P}$ & 0,007 \\
\hline
\end{tabular}

According to factorial ANOVA method, it was observed that number of individuals in the family effects "emotional responsiveness" together with father's occupation. But no difference was determined among occupational groups with
Spearman correlation method (Table 7).

Table 7. Correlation analysis among occupational groups.

\begin{tabular}{|c|c|c|c|}
\hline Source & $\begin{array}{l}\text { Sum of TypeIII } \\
\text { square }\end{array}$ & Mean square & $\mathbf{P}$ \\
\hline Father's occupation & ,781 & ,195 &, 727 \\
\hline Father's occupation* & & & \\
\hline $\begin{array}{l}\text { Number of individuals in the } \\
\text { family }\end{array}$ & 4,08 & 1.022 & 0.032 \\
\hline
\end{tabular}

It was observed that father occupation was not effective on showing required interest factor. But a significant relation was observed between regular reading and showing required interest factor (Table 8).

In a mutual comparison on showing required interest, the average of regular readers was 1,82 $\pm 0,46$ and average of non-readers was $1,99 \pm 0,5(\mathrm{p}=0,003)$. Average of regular readers was lower than non readers as the demonstrator of the positive situation.

Table 8. Mutual effect of other factors on "showing required interest" factor.

\begin{tabular}{|c|c|c|c|c|c|}
\hline Source & Sum of TypeIII square & Degree of freedom & Mean square & $\mathbf{F}$ & $\mathbf{P}$ \\
\hline Model & 1044,102 & 30 & 34.803 & 159.890 &, 000 \\
\hline Father's occupation & ,802 & 4 & ,200 & ,869 & ,483 \\
\hline Gender &, 487 & 1 & ,487 & 2.111 & , 147 \\
\hline Reg. Rea. Rt. & 1,791 & 1 & 1,791 & 7,793 & ,006 \\
\hline Age & ,315 & 1 & ,315 & 1.365 & ,244 \\
\hline Nb. Fam. Ind. & 1,166 & 1 & 1.166 & 5.055 &, 025 \\
\hline Father's occupation * Reg. Sp. Rt. & ,432 & 4 & , 108 & ,468 &, 759 \\
\hline Father's occupation * Reg. Rea. Rt. & 1,121 & 4 &, 280 & 1.215 & ,305 \\
\hline Father's occupation $*$ age & ,989 & 4 & ,247 & 1.072 & ,371 \\
\hline Father's occupation * Nb. Fam. Ind. & ,394 & 4 & ,098 & ,427 &, 789 \\
\hline Error & 58,817 & 255 & ,231 & & \\
\hline Total & 1102,918 & 285 & & & \\
\hline
\end{tabular}

a R score =,947 (Corrected R Score=,940), Reg. Sp. Rt. = Regular sport, Reg. Rea. Rt. = Regular reading, Nb. Fam. Ind. = Number of individuals in the family 
It was observed that with Factorial ANOVA method, Father's occupation and regular reading were mutually effective on general functions factor (Table 9). Using MANN
WHITNEY $U$ and WILCOXON W method, it was determined that general functions were better in adolescents reading regularly and whose fathers are educators.

Table 9. Mutual effect of other factors on "General Functions" factor.

\begin{tabular}{|c|c|c|c|c|c|}
\hline Source & Sum of TypeIII square & Degree of Freedom & Mean square & $\mathbf{F}$ & $\mathbf{P}$ \\
\hline Model & 912.258 & 30 & 30.409 & 82.007 & 000 \\
\hline Father's occupation & ,699 & 4 &, 175 &, 472 & ,757 \\
\hline Gender & ,305 & 1 & ,305 &, 824 & ,365 \\
\hline Reg. Sp. Rt. & 1,440 & 1 & 1.440 & 3.884 &, 050 \\
\hline Reg. Rea. Rt. & 2,378 & 1 & 2.373 & 6.412 &, 012 \\
\hline Age &, 001 & 1 &, 001 & ,003 & ,957 \\
\hline Nb. Fam. Ind. & 2,246 & 1 & 2.246 & 6.056 &, 015 \\
\hline Father's occupation * gender &, 246 & 4 &, 061 &, 166 & ,956 \\
\hline Father's occupation * Reg. Sp. Rt. & ,227 & 4 &, 057 &, 153 & ,961 \\
\hline Father's occupation * Reg. Rea. Rt. & 4,525 & 4 & 1,131 & 3,051 &, 018 \\
\hline Father's occupation * age & ,951 & 4 &, 230 &, 621 & ,648 \\
\hline Father's occupation * Nb. Fam. Ind. & 1,790 & 4 & ,448 & 1.207 & ,308 \\
\hline Error & 94,555 & 255 & ,372 & & \\
\hline Total & 1006,813 & 285 & & & \\
\hline
\end{tabular}

a R score =,906 (Corrected R Score =,895), Reg. Sp. Act.= Regular sport, Reg. Rea. Act.= Regular reading, Nb. Fam. Ind.= Number of individuals in the family

\section{Discussion}

Together with regular reading, father's occupation effects communication, emotional responsiveness and general functions of the adolescent. Presence of a significant difference among occupational groups was also checked in our study. It was observed that communication and general functions were better in the group of participants whose fathers are educators.

Available education systems, children using multimedia tools unconsciously prevent the creativity and criticism ability of individuals. We also think that educators are more aware of this fact compared to other parents and as a result, communication and general functions are better in adolescents whose parents are educators.

Nowadays children and adolescents prefer television and computers over reading. This prevents judgement and analysis ability of the individual. Individuals have difficulty in expressing themselves and finding solutions to problems they face. Parallel to this, we observed that reading effects "showing required interest" function by itself and communication and general functions mutually with father's occupation.

Adolescence is one of the milestones in human life. Future of the individual is mostly formed in this period. This is why children upbringing method of parents is important.

Child upbringing method of the parent is affected by many factors. One of these factors is father's occupation. Educators are more aware of education system related mistakes, so it is expected that the attitude of these parents towards the problems of the adolescents should be different.

We think that the reason is the fact that educators have a different view towards child upbringing, better communication skills and they encourage their children to read more.

If other occupation groups have more information on subjects such as life-long education, communication and regular reading, family functions of adolescents would be better.

Lack of reading habit makes the creativity, communication with other people and self-expression of individuals harder. Organizing programs for encouraging adolescents to read would increase reading rates.

Programs about child upbringing should not be prepared for mothers only and fathers should be encouraged to participate in these programs. So fathers who have information on this subject would approach their children differently and this would positively effect their development. Family physicians evaluating an individual as a whole have important roles on this subject.

\section{References}

[1] Goldenberg I, Goldenberg H. Family Therapy. An Overview, Third Edition. California: 1990.

[2] Aile içi Uyumlu etkileşim - T.C. Anadolu Üniversitesi yayını No: 2688, Açıköğretim Fakültesi yayını No: 1654

[3] Bilgiç N. ergenlik. http://yayim.meb.gov.tr, 2004

[4] Hines A. M. Divorce related transitions, adolescent development and the role of the parent-child relationship. Journel of Marriage and Family. 2 (59), 375- 388:1997.

[5] Epstein N. B., v.d. "The McMaster Model: View of Healthy Family Functioning", Normal Family Precesse (Ed. Froma Walsh), New York: The Guilford Pres.1993.

[6] 1-McWhirter H. ve Ark. "Family Counseling Interventions Understanding Family Systems And The Referral Process", Interventions In School And Clinic 1993: 28:4.

[7] Cotton N.S. "Discouting Adolescent Angst As Naturel Could Be Dangerous For Suicidal Tees" BrownUniversity Child and Adolescent Behavour Letter, 10:6:1994.

[8] Berns, M. R. Child, Family and Community, Florida: Harcourt Brace Collage Publishers,1993. 
[9] Tulkin S. R. "Social Class Differeces In Maternal and Infant Behavior", Culture and Infancy: Variations In The Human Experience (Ed. P. Herbert Leiderman, Steven R. Tulkin, Anne Rosenfeld), New York: Academic Pres, 1977.
[10] Bulut I. Aile Değerlendirme Ölçeği El Kitabı. Ankara: Özgüzeliş Matbaası,1990. 